\title{
Environmental Impact of Bamboo Laminated Flooring and Bamboo Scrimber Flooring Investigated via Life Cycle Assessment
}

\author{
Xiang Yu, ${ }^{\mathrm{a}}$ Lizhen Zeng, ${ }^{\mathrm{a}}$ Guofang Zhang, ${ }^{\mathrm{d}}$ and Hankun Wang ${ }^{\mathrm{b}, \mathrm{c}, *}$ \\ Bamboo floorings are the most important industrial products in the \\ bamboo sector. With the aim of providing a useful guide for the \\ development of bamboo floorings, this study quantitatively assessed the \\ environmental impacts of the two primary types of bamboo floorings, \\ laminated flooring and scrimber flooring, using life cycle assessment \\ (LCA) software SimaPro. The purpose of this study was to find out which \\ type of bamboo flooring is more environmentally friendly through \\ quantitatively analyzing the input and output of materials and energy \\ during the whole life cycle of the two types of flooring products. The \\ present study demonstrated that the majority of the environmental \\ burdens were associated with the process of bamboo strip production for \\ bamboo laminated flooring (59.3\%), and the process of panel processing \\ for bamboo scrimber floorings (56.9\%). In terms of environmental loads, \\ bamboo laminated flooring was considered more sustainable than \\ bamboo scrimber flooring, as the total environmental loads of bamboo \\ scrimber flooring was approximately 1.6 times that of bamboo laminated \\ flooring.
}

Keywords: Bamboo laminated flooring; Bamboo scrimber flooring; Life cycle assessment; Environmental loads

Contact information: a: Modern Education Center, Putian University, Putian, Fujian, 3511000, China; b: Department of Biomaterials, International Center for Bamboo and Rattan, Beijing 100102, China; c: SFA and Beijing Co-built Key Laboratory of Bamboo and Rattan Science \& Technology, State Forestry Administration, Beijing 100102, China; d: College of Forestry, Fujian Agriculture and Forestry

University, Fuzhou 350002, China; *Corresponding author: wanghankun@icbr.ac.cn

\section{INTRODUCTION}

Bamboo is an important forest resource and being explored as a wood substitute (Verma et al. 2014). Bamboo is attractive because it is ready for harvest in 3 to 5 years, has a greater yield per hectare, and much higher strength than traditional timber resources (Dixon and Gibson 2014). China is reported to have both the largest and fastest growing bamboo sector, and the primary use of local bamboo is bamboo flooring, which accounts for a major part of China's bamboo export (Jim et al. 2015). Two primary types of bamboo flooring are bamboo laminated flooring and bamboo scrimber flooring. However, due to technical limitations, the manufacturing process can still give rise to a series of environmental problems such as water pollution and greenhouse gas emissions, such as carbon dioxide, methane, and hydrogen fluoride (Li et al. 2016). Moreover, it is difficult to accurately estimate bamboo's environmental impact due to variability in growth and production (Escamilla and Habert 2014). Therefore, this study aimed to gain a better understanding of the environmental impact of industrial bamboo products using generally accepted methods. 
Life cycle assessment (LCA) is an internationally accepted standardized method to assess the potential environmental impact of products and services (Salzer et al. 2017). A few studies have applied LCA on bamboo or bamboo products (Vogtländer et al. 2010; Li et al. 2016; Agyekum et al. 2017). This study compares the environmental impact of bamboo laminated flooring and bamboo scrimber flooring based on the relevant international standards ISO 14040 (2006) and 14044 (2006) and the Chinese national standards GB/T 24040 (2008) and GB/T 24044 (2008).

\section{EXPERIMENTAL}

\section{Materials and Methods}

Processing procedure of bamboo laminated flooring and bamboo scrimber flooring

The processing procedures for the two types of flooring, bamboo laminated and scrimber, are shown in Fig. 1. The bamboo laminated material consists of various layers of laminated bamboo strips. The process is efficient and can preserve the natural texture and color of bamboo. However, the final products only utilize approximately $30 \%$ of the raw inputs, as a great part of materials are planed off to form rectangular sections (Sharma et al. 2015). Currently, bamboo laminated flooring takes up the largest market share in the bamboo flooring industry. Bamboo scrimber material is a new type of composite material with high strength and extensive raw material sources. It is made by grinding and fibrillating raw bamboo material into vertically consistent, horizontally loose, and closely interlacing strands, which will then go through a complicated process of drying, resin dipping, second drying, mat formation, and high-pressure molding. Bamboo scrimber material has good physical and mechanical properties, beautiful patterns, and vivid colors, bearing a great resemblance to natural wood in terms of texture. Moreover, the utilization ratio of raw bamboo material in the production process normally exceeds 60\% (Qin and Yu 2009).

\section{Life Cycle Assessment (LCA)}

A popular LCA software SimaPro (PRé Sustainability, v.7.1, Leiden University, Leiden, Netherlands), applying LCI database of Ecoinvent v2, is used to assess the environmental impact throughout the life cycle of a product or an activity. Its core purpose is to "conduct a comprehensive assessment of the environmental impact caused by all the processes, including production, use, recycle, and disposal". By collecting and quantifying the data of consumption and emission of energy and substance throughout the whole life cycle and assessing the impact of above-mentioned processes on the environment, LCA aims to develop targeted approaches to alleviate these environmental impacts. Thus far, LCA has been widely applied and used in many fields, such as construction (Chau et al. 2015), industrial chemistry (Tufvesson et al. 2013), new materials (Kim et al. 2016), food processing (Roy et al. 2009), and forestry (Verma et al. 2002). Eco-indicator is currently the most commonly used LCA method, which defines 11 types of environmental impacts and the computation process includes classification, characterization, normalization, and weighting. The first stage involves categorizing the data collected based on impact types. For characterization, one must multiply the data under each category with their corresponding characterization coefficient, add the numbers up, and obtain 11 quantified results of environmental damage. Then, the results are normalized and added up according to the categories, rendering three major 
categories of damage results: Human Health, Ecosystem Quality, and, Resources. Finally, the three major categories are weighted and the numbers added, resulting in a single score of the total environmental loads, as shown in Fig. 2.

\begin{tabular}{|c|c|c|c|c|c|c|c|c|c|}
\hline & \multicolumn{7}{|c|}{ Substance } & \multicolumn{2}{|c|}{ Energy } \\
\hline $\begin{array}{c}\text { Raw } \\
\text { bamboo }\end{array}$ & $\begin{array}{l}\text { Hydrogen } \\
\text { Peroxide }\end{array}$ & $\begin{array}{c}\mathrm{UF} \\
\text { resin }\end{array}$ & $\begin{array}{l}\text { UV } \\
\text { paint }\end{array}$ & $\begin{array}{l}\text { PE shrinkable } \\
\text { film }\end{array}$ & \begin{tabular}{|c|} 
Corrugated \\
paper carton
\end{tabular} & $\begin{array}{c}\text { Abrasive } \\
\text { paper }\end{array}$ & Water & Electricity & Heat \\
\hline
\end{tabular}

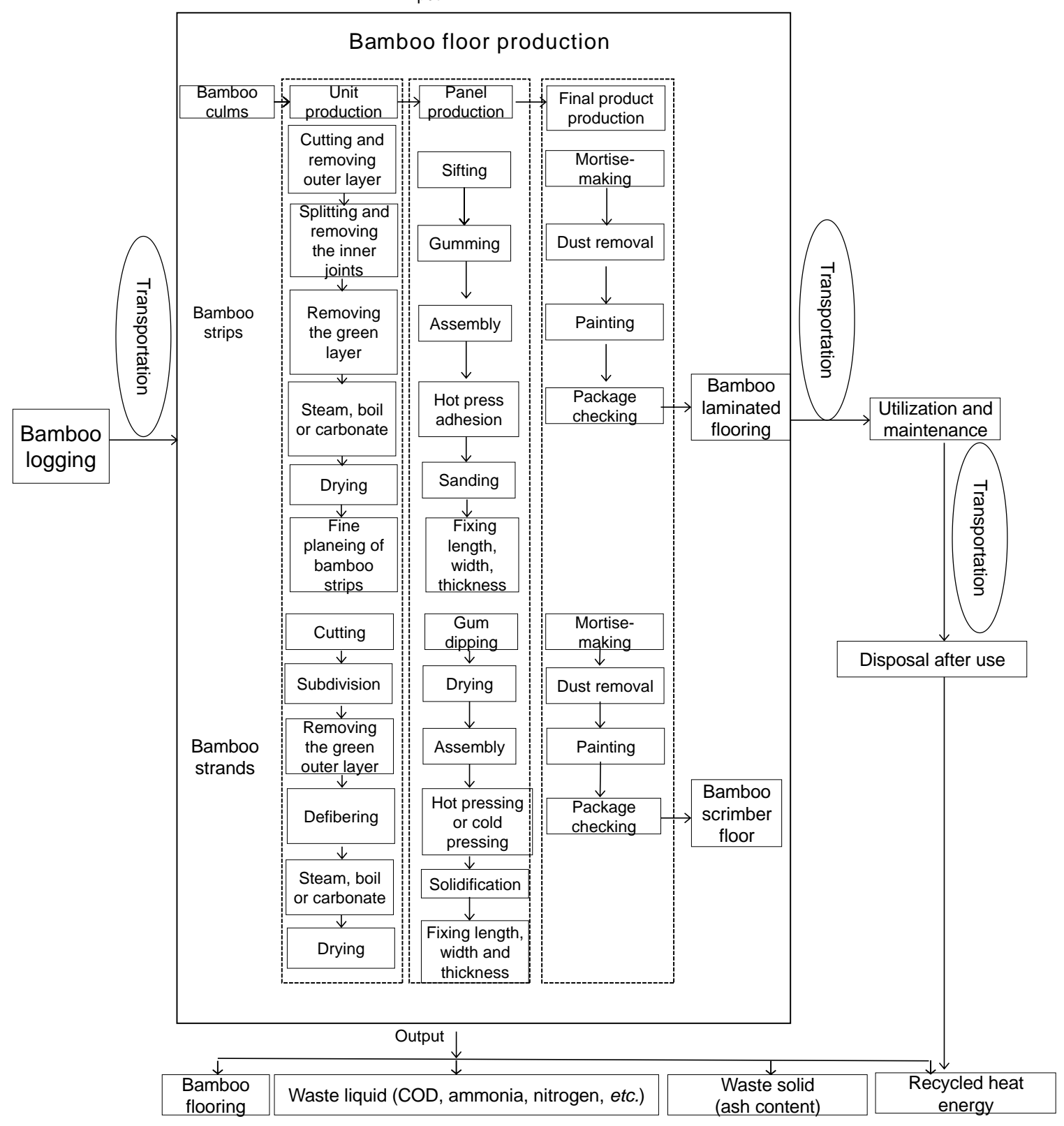

Fig. 1. Life cycles of two bamboo flooring products and the inputs and outputs during each stage 


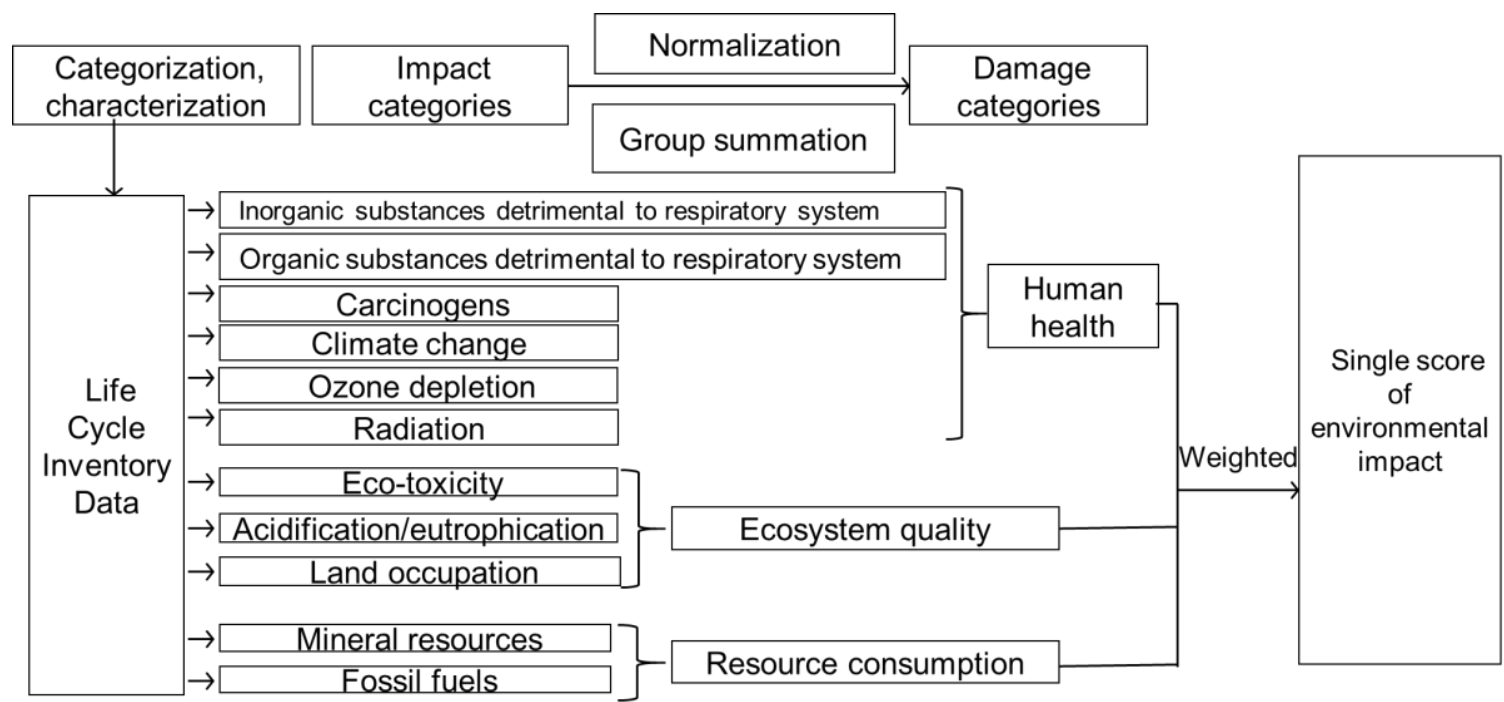

Fig. 2. Implementation steps of Eco-indicators 99

\section{Life cycle inventory analysis}

In reference to existing foreign LCA studies on solid wood, the functional unit chosen in this study was $1 \mathrm{~m}^{2}$ of bamboo flooring. Considering the characteristics of bamboo flooring production and the principles of LCA, the system product boundary was designated to include the whole life cycle of bamboo flooring, from the collection of raw materials, processing of bamboo strips (strands), panel production, final products production, and use to disposal (Fig. 1).

By investigating and collecting data from three major bamboo flooring manufacturers in the Zhejiang and Sichuan Provinces of China, a set of original data spanning from 2005 to 2009 on the amount of raw materials and energy needed to produce one functional unit of bamboo floorings was obtained. The basic data were then sifted, computed, and recalculated to obtain average values of the data from 2005 to 2009. Both types of bamboo floorings are produced with a high-temperature thermal treatment. The size of bamboo scrimber flooring was $910 \mathrm{~mm} \times 125 \mathrm{~mm} \times 14 \mathrm{~mm}$, the adhesive was phenolic resin, and the molding techniques were cold-pressing and thermosetting. The size of bamboo laminated flooring was $970 \mathrm{~mm} \times 97 \mathrm{~mm} \times 15 \mathrm{~mm}$, and urea-formaldehyde resin was used as an adhesive. It was assumed that the longevity of both types of bamboo flooring was 20 years and the geographical boundary was within China. The environmental loads inventory for both floorings is shown in Table 1.

Among the input items, bamboo raw material refers to the bamboo (calculated by absolute dry weight) consumed in producing $1 \mathrm{~m}^{2}$ of bamboo flooring of the designated type. The data for other raw materials consumed in the production process, such as adhesives, polyurethane paint, water, polyethylene (PE) shrinkable film, and corrugated carton were all provided by the manufacturers. The consumption of electricity and heat were recalculated based on the original data provided by the manufacturers. The heat used by the three above-mentioned manufacturers were all generated by the processing residues, and the solid waste after combustion was the ash content. Finally, the Lower Heating Value (LHV) of the bamboo raw material and bamboo flooring was set at 18.87 $\mathrm{MJ} / \mathrm{kg}$, according to relevant literature (Wang 2007). 
Table 1. Input and Output Inventory for Producing $1.0 \mathrm{~m}^{2}$ of Bamboo Laminated Flooring and Bamboo Scrimber Flooring

\begin{tabular}{|c|c|c|c|c|c|}
\hline & \multirow[b]{3}{*}{ Item } & \multirow[b]{3}{*}{ Unit } & \multirow{2}{*}{\multicolumn{2}{|c|}{$\frac{\text { Number }}{\text { Input }}$}} & \multirow[b]{3}{*}{ Notes } \\
\hline & & & & & \\
\hline & & & $\begin{array}{l}\text { Bamboo } \\
\text { Laminated } \\
\text { Flooring }\end{array}$ & $\begin{array}{l}\text { Bamboo } \\
\text { Scrimber } \\
\text { Flooring }\end{array}$ & \\
\hline \multirow{6}{*}{ Substance } & $\begin{array}{l}\text { Bamboo } \\
\text { Raw Material } \\
\text { (Absolute } \\
\text { Dry Weight) }\end{array}$ & $\mathrm{kg}$ & 35.1 & 19.6 & $\begin{array}{l}\text { The density of bamboo } \\
\text { scrimber is } 1.07 \mathrm{~g} / \mathrm{cm}^{3} \text {; the } \\
\text { water content of the final } \\
\text { product is } 8 \% \text {; the } \\
\text { adhesive content is } 10 \% \\
\text { and the material utilization } \\
\text { ratio is } 60 \% \text {. The density of } \\
\text { bamboo laminated flooring } \\
\text { is } 0.8 \mathrm{~g} / \mathrm{cm}^{3}, \text { the water } \\
\text { content of final product is } \\
8 \% \text {, the adhesive content is } \\
4.5 \% \text {, and the material } \\
\text { utilization ratio is } 30 \% \text {. }\end{array}$ \\
\hline & UF Resin & $\mathrm{kg}$ & 0.45 & 1.38 & $\begin{array}{l}\text { Calculated based on the } \\
\text { number of consumed } \\
\text { adhesives }\end{array}$ \\
\hline & UV Paint & $\mathrm{kg}$ & 0.16 & 0.16 & $\begin{array}{l}\text { Averaged value of the data } \\
\text { provided by } 3 \\
\text { manufacturers }\end{array}$ \\
\hline & $\begin{array}{l}\text { PE } \\
\text { Shrinkable } \\
\text { Film }\end{array}$ & $\mathrm{kg}$ & 0.06 & 0.06 & $\begin{array}{c}\text { Averaged value of the data } \\
\text { provided by } 3 \\
\text { manufacturers (including } \\
\text { foam cushion) }\end{array}$ \\
\hline & $\begin{array}{l}\text { Corrugated } \\
\text { Paper Box }\end{array}$ & $\mathrm{kg}$ & 0.32 & 0.32 & $\begin{array}{l}\text { Averaged value of the data } \\
\text { provided by } 3 \\
\text { manufacturers }\end{array}$ \\
\hline & Water & $\mathrm{kg}$ & 45 & 55 & $\begin{array}{c}\text { Original data provided by } 1 \\
\text { manufacturer }\end{array}$ \\
\hline \multirow[t]{2}{*}{ Energy } & Electricity & kWh & 8.8 & 11.1 & $\begin{array}{l}\text { Averaged value of the data } \\
\text { provided by } 3 \\
\text { manufacturers }\end{array}$ \\
\hline & Heat & MJ & 339 & 719 & $\begin{array}{c}\text { Original data provided by } 1 \\
\text { manufacturer }\end{array}$ \\
\hline \multicolumn{6}{|c|}{ Output } \\
\hline $\begin{array}{l}\text { Combustion } \\
\text { emission }\end{array}$ & \multicolumn{5}{|c|}{$\begin{array}{l}\text { The environmental impact caused by the combustion of process waste is } \\
\text { calculated based on the data of timber, as provided in the SimaPro software } \\
\text { database. The items will not be fully elaborated due to length limits. }\end{array}$} \\
\hline Formaldehyde & $\mathrm{CH}_{2} \mathrm{O}$ & $\mathrm{kg}$ & $9.9 \mathrm{E}-4$ & $4.45 E-4$ & $\begin{array}{c}\text { Calculated based on the } \\
\text { upper limit of the Chinese } \\
\text { national standard (GB } \\
18580(2001)\end{array}$ \\
\hline \multirow[b]{2}{*}{ Waste liquid } & COD & $\mathrm{kg}$ & 1.60E-4 & $1.60 \mathrm{E}-4$ & \\
\hline & $\begin{array}{l}\text { Ammonia } \\
\text { nitrogen }\end{array}$ & $\mathrm{kg}$ & $7.40 \mathrm{E}-6$ & $7.40 \mathrm{E}-6$ & \\
\hline
\end{tabular}


Among the output items, the gas emission generated in the combustion of processing residues was calculated using the numbers of "Heat wood B250", as provided in the SimaPro database, because the chemical composition of bamboo and wood are basically the same, and the types and amount of gas emitted during their combustion are also similar. The solid waste after combustion was the ash content, which accounted for approximately $0.96 \%$ of the bamboo material's absolute dry weight.

To compare the environmental loads of the two products during each production stage, their production process was divided into three technical stages: unit production (bamboo strips or bamboo strand), panel production, and final product production. The manufacturing data were categorized accordingly and the environmental load inventory of each product at different stages is shown in Table 2. The data source was the same as in Table 1.

Table 2. Input and Output Inventory at Different Stages of Bamboo Laminated Flooring and Bamboo Scrimber Flooring Production

\begin{tabular}{|c|c|c|c|c|c|c|c|c|}
\hline & \multirow{4}{*}{ Item } & \multirow{4}{*}{ Unit } & \multicolumn{6}{|c|}{ Number } \\
\hline & & & \multicolumn{6}{|c|}{ Inputs } \\
\hline & & & \multicolumn{3}{|c|}{ Bamboo laminated flooring } & \multicolumn{3}{|c|}{ Bamboo scrimber flooring } \\
\hline & & & $\begin{array}{l}\text { Bamboo } \\
\text { strip }\end{array}$ & $\begin{array}{c}\text { Bamboo } \\
\text { panel }\end{array}$ & $\begin{array}{c}\text { Final } \\
\text { product }\end{array}$ & $\begin{array}{l}\text { Bamboo } \\
\text { strand }\end{array}$ & $\begin{array}{c}\text { Bamboo } \\
\text { panel }\end{array}$ & $\begin{array}{l}\text { Final } \\
\text { product }\end{array}$ \\
\hline \multirow{5}{*}{ Substance } & UF Resin & $\mathrm{kg}$ & - & 0.45 & - & - & 1.38 & - \\
\hline & UV Paint & $\mathrm{kg}$ & - & - & 0.080 & - & - & 0.16 \\
\hline & $\begin{array}{c}\mathrm{PE} \\
\text { Shrinkable } \\
\text { Film }\end{array}$ & $\mathrm{kg}$ & - & - & 0.024 & - & - & 0.06 \\
\hline & $\begin{array}{l}\text { Corrugated } \\
\text { Paper } \\
\text { Carton }\end{array}$ & $\mathrm{kg}$ & - & - & 0.202 & - & - & 0.32 \\
\hline & Water & $\mathrm{kg}$ & 40 & 5 & - & 55 & 5 & - \\
\hline \multirow[t]{2}{*}{ Energy } & Electricity & kWh & 5 & 1 & 2.8 & 2.5 & 6 & 2.61 \\
\hline & Heat & MJ & 317 & 34.0 & - & 305.7 & 339.7 & - \\
\hline \multicolumn{9}{|c|}{ Outputs } \\
\hline $\begin{array}{l}\text { Combustion } \\
\text { emission }\end{array}$ & \multicolumn{8}{|c|}{$\begin{array}{l}\text { The environmental impact caused by the combustion of process waste is calculated } \\
\text { based on the data of timber as provided in the SimaPro database. The items will not } \\
\text { be fully elaborated due to length limits. }\end{array}$} \\
\hline $\begin{array}{l}\text { Formalde- } \\
\text { hyde }\end{array}$ & $\mathrm{CH}_{2} \mathrm{O}$ & $\mathrm{kg}$ & - & $4.45 \mathrm{E}-4$ & - & - & $4.45 E-4$ & - \\
\hline \multirow{2}{*}{ Waste liquid } & COD & $\mathrm{kg}$ & $1.60 \mathrm{E}-4$ & - & - & $1.60 \mathrm{E}-4$ & - & - \\
\hline & $\begin{array}{l}\text { Ammonia- } \\
\text { nitrogen }\end{array}$ & $\mathrm{kg}$ & $7.40 \mathrm{E}-6$ & - & - & $7.40 \mathrm{E}-6$ & - & - \\
\hline
\end{tabular}

Environmental loads also exist when the flooring is in use. The input and output data of substances and energy during the utilization and maintenance of the flooring were calculated according to the habitual cleaning routines of people living in China, and the average value was adopted as the final data. In this stage, only water was consumed. The 
data were obtained by calculation based on the Chinese citizen's water-use habits. During the 20 years of its service life, every functional unit of flooring is assumed to consume around 820 liters of water. It is assumed that the flooring is not recycled or reused and that the wastes are all recycled through combustion. The heat produced during the combustion process was calculated by multiplying the mass of the discarded floor by the LHV $(18.87 \mathrm{MJ} / \mathrm{kg})$. The solid waste after the combustion is the ash content, accounting for $0.96 \%$ of the total mass. Heat recovery reduces the consumption of standard coal, so the environmental loads it reduces is credited to this stage. Meanwhile, the emission caused by the combustion of bamboo residues is also included in the disposal stage. The environmental burden inventory of both types of bamboo flooring is shown in Table 3.

Table 3. Environmental Load Inventory at the Disposal Stage of Bamboo Laminated Flooring and Bamboo Scrimber Flooring

\begin{tabular}{|c|c|c|c|c|c|}
\hline & \multirow[b]{2}{*}{ Materials } & \multirow[b]{2}{*}{ Unit } & \multicolumn{2}{|c|}{ Inputs/Outputs } & \multirow[b]{2}{*}{ Notes } \\
\hline & & & $\begin{array}{l}\text { Bamboo laminated } \\
\text { flooring }\end{array}$ & $\begin{array}{l}\text { Bamboo scrimber } \\
\text { flooring }\end{array}$ & \\
\hline $\begin{array}{l}\text { Combustion } \\
\text { Emissions }\end{array}$ & \multicolumn{5}{|c|}{$\begin{array}{l}\text { The emission caused by the combustion of process waste is calculated based on } \\
\text { the data of timber, as provided in the SimaPro software database. The items will } \\
\text { not be fully elaborated due to length limits. }\end{array}$} \\
\hline Solid Waste & Ash & kg & $1.07 \mathrm{E}-1$ & $1.28 \mathrm{E}-1$ & $\begin{array}{c}\text { The amount of } \\
\text { ash content is } \\
0.96 \% \text {. }\end{array}$ \\
\hline $\begin{array}{c}\text { Heat } \\
\text { Recovery }\end{array}$ & & MJ & -207 & -251 & $\begin{array}{c}\text { The LHV is } 18.87 \\
\mathrm{MJ} / \mathrm{kg}\end{array}$ \\
\hline
\end{tabular}

The life cycle of bamboo flooring during the production stage includes 4 transportation stages, namely the transportation of raw materials to manufacturers, from the manufacturers to the shopping malls, from the shopping malls to the households, and from the households to the dumpsites. This article included the environmental loads resulting from each transportation into the stage that followed the transportation process. For instance, the transportation consumption during the process of moving bamboo raw materials to bamboo processing factories is included in the flooring production stage. The transportation consumption during the process of moving the final products to the households of flooring consumers is included in the utilization stage and so forth. The vehicle models used for transportation and associated transporting capacities were chosen in the databases of SimaPro, and the transportation distance was set from 20 to $30 \mathrm{~km}$.

The manufacturing process consumes electricity, which results in environmental emissions. Considering that in China electricity mainly comes from thermal power, this article selected the data inventory of coal-fired power from the database provided by SimaPro. The environmental load inventory of adhesive production comes from the Ecoinvent database. The data inventory of ultraviolet (UV) lacquer, PE shrink film, and corrugated carton was taken from the ETH database provided by SimaPro.

Formaldehyde emissions of bamboo flooring during their entire life cycle are estimated by using the upper limit prescribed by the national standards and are equally allocated to two stages: production and utilization. The data used for the component analysis of liquid waste produced during bamboo flooring production comes from reference literature (Wang 2007). The content of total suspended particles (TSPs) during 
the process of bamboo flooring production cannot be accurately measured and is thus omitted from calculation in this article.

\section{RESULTS AND DISCUSSION}

\section{Impact Assessment of the Life Cycle of Bamboo Laminated Flooring}

According to the single scores of environmental loads resulting from three different processes of bamboo laminated flooring production, it was concluded that during the stages of production, the largest proportion of environmental loads come from the bamboo strip processing, accounting for $59.3 \%$, followed by the production of the final products (flooring), accounting for $21.1 \%$, and finally the production of bamboo panels, accounting for $18 \%$. During the production process of bamboo laminated flooring, the environmental loads resulting from bamboo strip production was over two or three times that of the total during the bamboo panel's final product manufacturing. The reason was that during the stage of bamboo strip production, electricity, thermal energy, and water resources were readily consumed and the volume of water body discharge was larger than in the other two stages. Therefore, reducing electricity and energy consumption during the stage of bamboo strip preparation is vital to reduce the environmental burden.

As shown in Fig. 3, by comparing the three stages of bamboo laminated flooring production, the results showed that bamboo strip manufacturing had the greatest impact on eight environmental impact categories, including carcinogens, organic substances detrimental to the respiratory system, inorganic substances detrimental to the respiratory system, climate change, ozone depletion, eco-toxicity, acidification/eutrophication, and land occupation. Two types of environmental loads, radiation and mineral consumption, were entirely produced during final product manufacturing. Additionally, most land occupation was caused by bamboo panel manufacturing. Through comparing the impact of each of the three production stages on human health, ecosystem quality, and resource consumption, it was concluded that among the three stages, with respect to human health, bamboo strip production had the largest impact, followed by final product manufacturing, with bamboo panel manufacturing having the least impact. With respect to the ecosystem quality, bamboo strip manufacturing had the largest impact, followed by bamboo panel manufacturing, and final product manufacturing. Regarding resource consumption, bamboo strip production had the largest impact, followed by final product manufacturing, and bamboo panel manufacturing.

\section{Impact Assessment of the Life Cycle of Bamboo Scrimber Flooring}

According to the environmental load single scores for bamboo scrimber flooring, it was concluded that during the stages of production, the largest proportion of environmental loads come from bamboo panel processing, accounting for $56.9 \%$, followed by bamboo strip manufacturing (26.6\%), and final product manufacturing (14.4\%). The environmental loads resulting from bamboo panel production was twice that of bamboo strip manufacturing and four times that of final product manufacturing. Therefore, reducing electricity and energy consumption during bamboo panel production is vital for making bamboo scrimber flooring more environmentally friendly. 


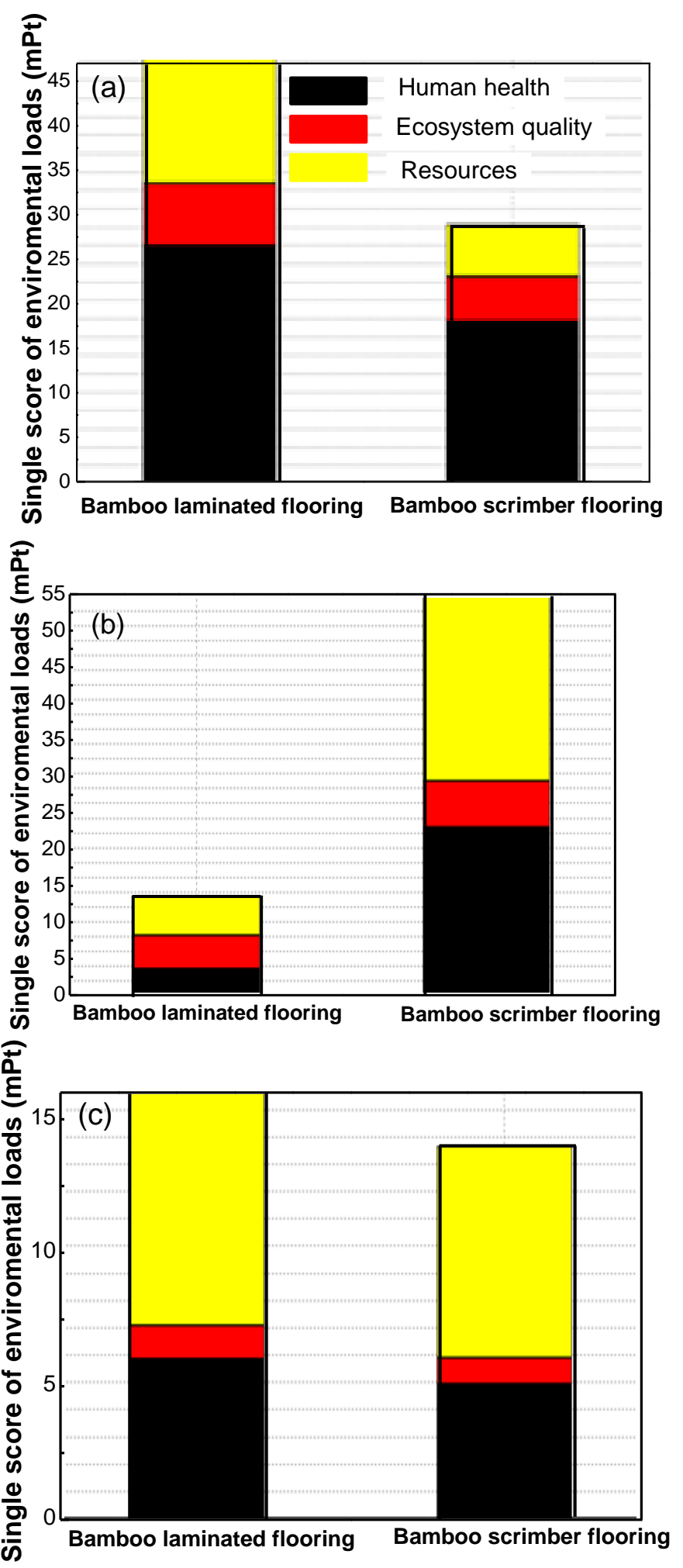

Fig. 3. Comparison single scores of environmental loads resulting between bamboo laminated flooring and scrimber flooring during the preparation stage: (a) bamboo strips or strands, (b) bamboo panels, and (c) final products 
Through a comparison of the three stages of bamboo scrimber flooring production, it was determined that the stage of bamboo panel manufacturing had the greatest impact on nine environmental impact categories. These categories included carcinogens, organic substances detrimental to the respiratory system, inorganic substances detrimental to the respiratory system, climate change, ozone depletion, ecotoxicity, acidification/eutrophication, land occupation, and fossil fuel combustion, followed by bamboo strip manufacturing and final product manufacturing. Two types of environmental loads, radiation and mineral consumption, were entirely produced during final product manufacturing. By comparing the impact of each of the three production stages on human health, ecosystem quality, and resource consumption, it was inferred that among the three stages, bamboo strip production had the largest impact on human health and ecosystem quality, followed by final product manufacturing and bamboo panel manufacturing. With respect to resource consumption, bamboo panel production had the largest impact, followed by final product manufacturing and bamboo strip manufacturing.

\section{Comparative Life Cycle Studies of the Two Types of Flooring}

The above-mentioned analyses showed that during the entire life cycles of bamboo laminated flooring and bamboo scrimber flooring, product manufacturing created the largest environmental loads while the stage of utilization barely had any negative impact on the environment. During the disposal stage, thermal energy from combustion is re-utilized, reducing coal consumption accordingly, so this stage has a positive impact on the environment instead of a negative influence.

By comparing the environmental load, as single scores for bamboo laminated flooring and bamboo scrimber flooring during their entire life cycles, it was clear that there were noticeable differences. Figure 3(a) shows a comparison between single scores of environmental loads caused by preparing $1 \mathrm{~kg}$ component units (bamboo strand and strip) of bamboo flooring. During the process of bamboo scrimber flooring manufacturing, the single score of preparing $1 \mathrm{~kg}$ of bamboo strand was approximately $28 \mathrm{mPt}$, while the single score of preparing $1 \mathrm{~kg}$ of bamboo strip was $46 \mathrm{mPt}$. Therefore, it can be concluded that in terms of preparing component units, bamboo scrimber flooring is more environmentally friendly than bamboo laminated flooring. The main reason for these results was that the preparation of bamboo strands adopted pressing techniques, and the electricity consumption during this process was half that of planning bamboo strip. In comparison, the energy consumption during the process of boiling was relatively low. However, Fig. 3(b) shows that bamboo laminated flooring was more environmentally friendly than bamboo scrimber flooring during the stage of bamboo panel manufacturing, where the single score of environmental loads resulting from the former was merely 14 $\mathrm{mPt}$, while that from the latter reached $54 \mathrm{mPt}$, which was almost 3 times higher. This was mainly because the production of bamboo panels for bamboo scrimber flooring adopted the technique of cold pressing and heat curing and used the phenolic resin, whose curing temperature is higher than urea resin. As a result, its electricity and energy consumption was greater than that of bamboo laminated flooring. Figure 3(c) shows that the environmental loads resulting from bamboo laminated flooring production were similar to that of bamboo scrimber flooring production during final product preparation, where the single score of the former was $15.7 \mathrm{mPt}$ and the latter $13.8 \mathrm{mPt}$. 


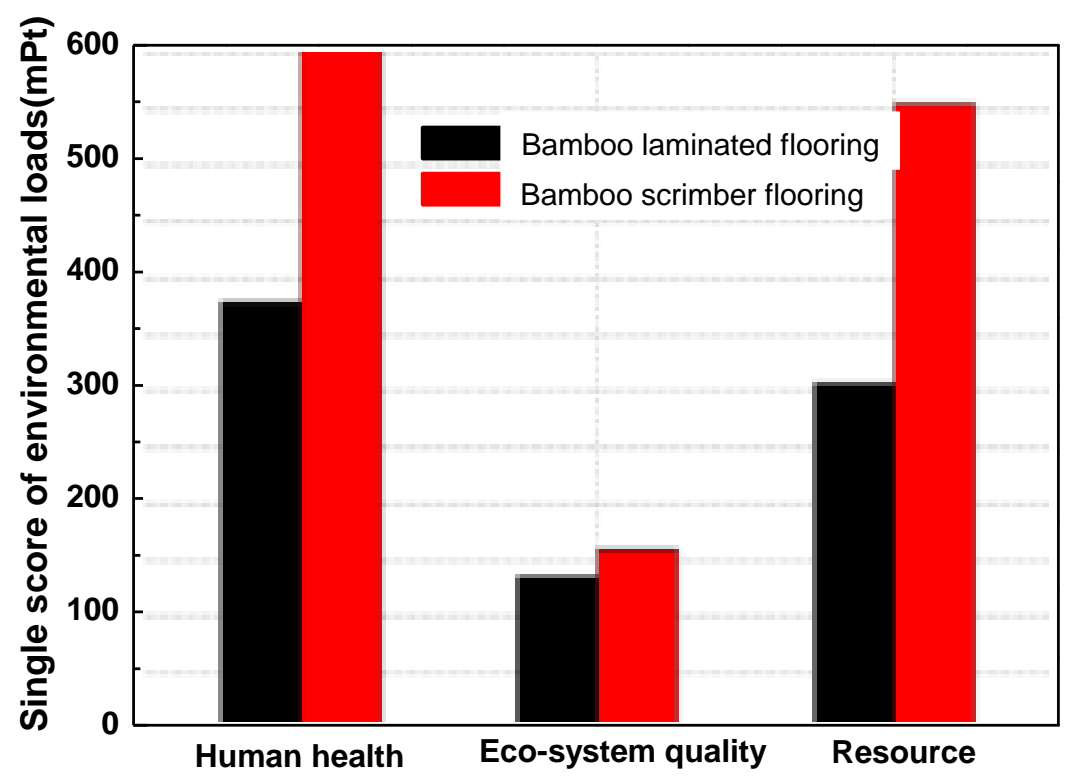

Fig. 4. Comparing single score of environmental loads between each of the three types of environmental loads for bamboo laminated flooring and scrimber flooring

Figure 4 shows the comparison between environmental load single scores for the two types of bamboo flooring for three environment categories. The results showed that in terms of human health, ecosystem quality, and resource consumption, the environmental loads resulting from bamboo scrimber flooring production were higher than that of bamboo laminated flooring production. The discrepancy was quite considerable in terms of human health and resource consumption, but rather small in terms of ecosystem quality. Figure 5 shows the comparison between the environmental load single scores of the two types of bamboo flooring.

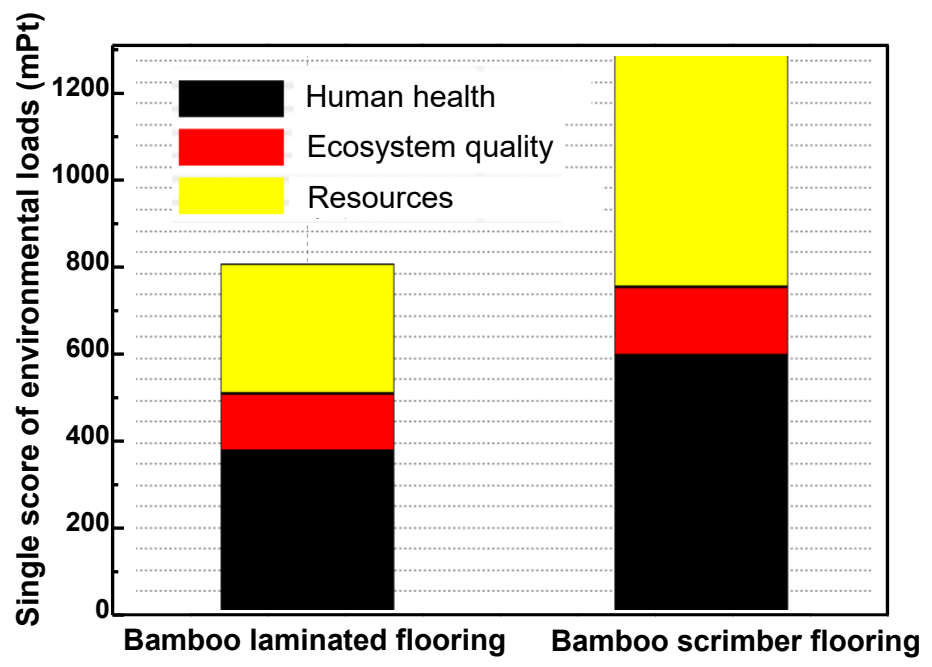

Fig. 5. Comparison between single scores of environmental loads of the two types of bamboo flooring. 
The single score of environmental loads of bamboo scrimber flooring was approximately $1320 \mathrm{mPt}$, while that of bamboo laminated flooring was merely $820 \mathrm{mPt}$, meaning that the former was 1.61 times that of the latter. The aforementioned results indicated that although bamboo scrimber flooring had a higher utilization rate of raw material and better economic performance, from the perspective of environment protection, bamboo scrimber flooring caused more negative impact on the environment than bamboo laminated flooring.

\section{CONCLUSIONS}

The environmental impact (LCA) of bamboo laminated flooring was compared to that of bamboo scrimber flooring. The main results from the study are as follows:

1. During the entire life cycles of bamboo laminated flooring and bamboo scrimber flooring, the stage of product manufacturing created the largest environmental loads, while the stage of product usage had minimal impact on the environment. During the disposal stage, thermal power from combustion is re-utilized, reducing coal consumption accordingly; thus this stage had an anticipated positive impact on the environment instead of a negative influence. Therefore, reducing electricity and energy consumption during bamboo strip preparation process is important to improve environment friendliness of bamboo laminated flooring.

2. During different stages of product manufacturing, the environmental impact of the two types of flooring varied greatly. During the production of bamboo laminated flooring, the process of manufacturing bamboo strips created the largest environmental loads, accounting for $59.3 \%$ of the total. During the production of bamboo scrimber flooring, the process of manufacturing bamboo panels created the largest environmental loads, accounting for $56.9 \%$ of the total.

3. The environmental loads caused by producing $1 \mathrm{~m}^{2}$ of bamboo scrimber flooring was approximately 1.61 times that of bamboo laminated flooring. Though bamboo scrimber flooring had a higher utilization rate of raw material and better economic performance, from the perspective of environment protection, bamboo scrimber flooring had a more negative environmental impact than bamboo laminated flooring.

\section{ACKNOWLEDGEMENTS}

The authors would like to thank the special fund under the Basic Scientific Research Funds of International Center for Bamboo and Rattan (1632018016) and the General Project of Fujian Higher Education Information Academy (2014FC004). 


\section{REFERENCES CITED}

Agyekum, E. O., Fortuin, K. P. J., and Harst, E. V. D. (2017). "Environmental and social life cycle assessment of bamboo bicycle frames made in Ghana," J. Clean. Prod. 143, 1069-1080. DOI: 10.1016/j.jclepro.2016.12.012

Chau, C. K., Leung, T. M., and Ng, W. Y. (2015). "A review on life cycle assessment, life cycle energy assessment and life cycle carbon emissions assessment on buildings," Appl. Energ. 143(1), 395-413. DOI: 10.1016/j.apenergy.2015.01.023

Dixon, P. G., and Gibson, L. J. (2014). "The structure and mechanics of moso bamboo material," J. R. Soc. Interface 11(99), 20140321. DOI: 10.1098/rsif.2014.0321

Escamilla, E. Z., and Habert, G. (2014). "Environmental impacts of bamboo-based construction materials representing global production diversity," J. Clean. Prod. 69(8), 117-127. DOI: 10.1016/j.jclepro.2014.01.067

GB 18580 (2001). "Limit of formaldehyde emission from artificial board and its products for indoor decoration," Standardization Administration of China, Beijing, China.

ISO 14040 (2006). "Life cycle assessment e. principles and framework," International Organization for Standardization, Geneva, Switzerland.

ISO 14044 (2006). "Life cycle assessment e. requirements and guidelines," International Organization for Standardization, Geneva, Switzerland.

Kim, J., Rivera, J. L., Meng, T. Y., Laratte, B., and Chen, S. (2016). "Review of life cycle assessment of nanomaterials in photovoltaics," Sol. Energy 133, 249-258. DOI: 10.1016/j.solener.2016.03.060

Li, J., Yuan, Y., and Guan, X. (2016). "Assessing the environmental impacts of gluedlaminated bamboo based on a life cycle assessment," BioResources 11(1), 19411950. DOI: 10.15376/biores.11.1.1941-1950

Qin, L., and Yu, W. (2009). "Status and prospects of reconstituted bamboo lumber," World Forestry Research 22(6), 55-59. (In Chinese)

Roy, P., Nei, D., Orikasa, T., Xu, Q. Y., Okadome, H., and Nakamura, N. (2009). “A review of life cycle assessment (LCA) on some food products," J. Food Eng. 90(1), 1-10. DOI: 10.1016/j.jfoodeng.2008.06.016

Salzer, C., Wallbaum, H., Ostermeyer, Y., and Kono, J. (2017). "Environmental performance of social housing in emerging economies: Life cycle assessment of conventional and alternative construction methods in the Philippines," Int. J. Life Cycle Ass. 22(11), 1785-1801. DOI: 10.1007/s11367-017-1362-3

Sharma, B., Gatóo, A., Bock, M., and Ramage, M. (2015). "Engineered bamboo for structural applications," Constr. Build Mater. 81, 66-73. DOI: 10.1016/j.conbuildmat.2015.01.077

Tufvesson, L. M., Tufvesson, P., Woodley, J. M., and Börjesson, P. (2013). "Life cycle assessment in green chemistry: Overview of key parameters and methodological concerns," Int. J. Life Cycle Assoc. 18(2), 431-444.

DOI: $10.1007 / \mathrm{s} 11367-012-0500-1$

Verma, C. S., Sharma, N. K., Chariar, V. M., Maheshwari, S., and Hada, M. K. (2014). "Comparative study of mechanical properties of bamboo laminae and their laminates with woods and wood-based composites," Compos. Part B-Eng. 60(2), 523-530. DOI: 10.1016/j.compositesb.2013.12.061

Verma, M., Dubey, S., and Bharadwaj, R. (2002). "Application of life cycle assessment to forestry products," Int. J. Life Cycle Assoc. 7(3), 187-188. DOI: 10.1007/BF02994076 
Vogtländer, J., Lugt, P. V. D., and Han, B. (2010). "The sustainability of bamboo products for local and western European applications, LCAs and land-use," J. Clean. Prod. 18(13), 1260-1269. DOI: 10.1007/s11367-012-0500-1

Wang, A. (2007). "The life cycle assessment of bamboo/wooden products and its application," Ph.D. Dissertation, Chinese Academy of Forestry, Beijing, China. (In Chinese)

Article submitted: February 15, 2019; Peer review completed: July 20, 2019; Revised version received: September 25, 2019; Accepted: September 26, 2019; Published: October 1, 2019.

DOI: 10.15376/biores.14.4.9132-9145 